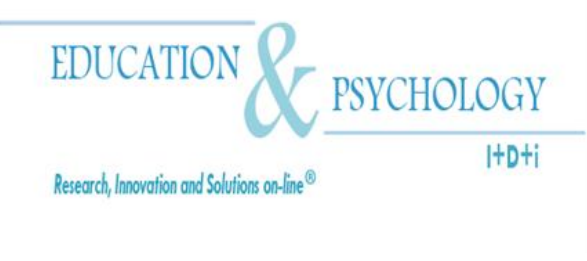

\title{
The Scope of Cooperative Work in the Classroom from the Viewpoint of Primary School Teachers
}

\author{
Mª P. Fernández-Lozano ${ }^{1}$, M. González-Ballesteros ${ }^{1}$, \\ A. De-Juanas ${ }^{2}$ \\ ${ }^{1}$ Departamento de Psicología Evolutiva y de la Educación, Universidad \\ Complutense de Madrid, Madrid \\ ${ }^{2}$ Departamento de Teoría de la Educación y Pedagogía Social, Universidad \\ Nacional de Educación a Distancia, Madrid
}

\section{Spain}

Correspondence: Ma Pilar Fernández-Lozano.c/ Rector Royo Villanova s/n, , 28040 Madrid. E-mail: pflozano@edu.ucm.es

(C) Education \& Psychology I+D+i and Editorial EOS (Spain) 


\begin{abstract}
Introduction. Different international organisms, including UNESCO, insist on the importance of collaborative teamwork to face today's challenges. This skill should be fostered from the early stages of education, and consequently, it is particularly important that Primary School teacher training institutions draw up proposals and implement new practices which include this type of work. This paper attempts to describe how a group of Primary School teachers perceive cooperative learning based on their interview responses.
\end{abstract}

Method. The methodology is based on a qualitative and descriptive approach using semistructured interviews. The interview content was analysed using the content analysis procedure. The sample included 48 Primary School teachers in the Madrid area who had been interviewed previously.

Results. The teachers' opinions refer to three key aspects: evaluation of the cooperative learning competence; action taken by teachers related to this competence; training received in this competence. The research findings suggest that teamwork is seldom used, and when it is used, this is basically for motivational reasons. The low importance given to this competence in initial teacher training is also mentioned.

Conclusion. The results suggest that the potential of collaborative work to facilitate learning and manage diversity is not generally understood.

Keywords: cooperative learning, professional competences, initial teacher training, primary teachers. 


\section{El alcance del trabajo cooperativo en el aula desde el punto de vista de los maestros de Educación Primaria Resumen}

Introducción. La sociedad actual requiere la necesidad de trabajar en equipo de forma colaborativa, como han señalado distintas instancias internacionales entre las cuales se encuentra la UNESCO. Esta capacidad debe ser entrenada desde la enseñanza básica. Por este motivo, cobra especial interés que desde los centros de formación del profesorado de primaria se elaboren propuestas y nuevas prácticas que consideren esta modalidad de trabajo. Nuestro estudio pretende describir la percepción de un grupo de maestros de primaria sobre el aprendizaje cooperativo a partir de sus manifestaciones.

Método. La metodología se inscribe dentro de un enfoque cualitativo de carácter descriptivo en el que se utilizó la entrevista semiestructurada. Para analizar el contenido de las entrevistas se utilizó el procedimiento de análisis de contenido. Se accedió a una muestra de 48 maestros de Educación Primaria de la Comunidad de Madrid a los que previamente se había encuestado.

Resultados. Las opiniones de los maestros hacen referencia a tres aspectos clave: la valoración sobre la competencia de aprendizaje cooperativo; la actuación del profesorado en relación a la misma; y la formación recibida en dicha competencia. Los hallazgos de esta investigación apuntan a una escasa utilización del trabajo en equipo, y cuando se lleva a cabo su orientación es fundamentalmente motivacional. Asimismo, se indica la escasa incidencia de la formación inicial en la capacitación del profesorado.

Conclusión. Los resultados dejan entrever que existe un amplio desconocimiento respecto a la potencialidad del trabajo colaborativo para facilitar el aprendizaje, así como el tratamiento de la diversidad.

Palabras Clave: aprendizaje cooperativo, competencias profesionales, formación inicial del profesorado, maestros.

Recibido: $29 / 12 / 11$

Aceptación inicial: 15/01/12

Aceptación final: 05/03/12 


\section{Introduction}

Teamwork is now a requirement since, as the UNESCO highlighted in 2005, a fundamental aim of society in the 21st century is the collective use of knowledge, mutual assistance and the management of new models of cooperative development. To do this, students must be able to work cooperatively throughout the different levels of their education, to heighten the educational potential of the group and the processes which take place within it. This requirement responds to the far-reaching global transformations which affect our social, economic, cultural and political environment. Society has become aware that education can be a tool that offers, and even guarantees a response to these new needs. This is reflected in the Delors Report (1997) which points out the need to envisage a wider concept of education.

The implementation of the European Higher Education Area (EHEA), on the other hand, has led universities to draw up a series of proposals and directives which represent an excellent opportunity to introduce new teaching practices to ensure lifelong learning, while taking into account that differences do exist in learning conditions and methods (Parcerisa Aran et al., 2005),. In short, the intention is to ensure competent future professionals who are able to apply, teach and communicate knowledge in a responsible manner within the framework of a changing society (Bologna Declaration, 1999; Graz Declaration, 2003; Glasgow Declaration, 2005 etc.). As a result, professional training means planning the learning processes and results based on the definition of the professional profiles of the different university qualifications (Hernández Pina, 2005). In the case considered here, this will refer to the primary education teaching qualification (Primary Education Teaching Degree). We understand that improving university teaching will have a significant effect on the future professional activity of the trainee teachers and this must include the opinion of practising teachers regarding the gaps in their training and the difficulties they experience in their day-to-day professional activity, and also a more detailed examination of the beliefs underlying their point of view.

This article shows the results of how practising teachers evaluate teamwork and how they conceptualize it through the way they organize classroom work. The authors consider that this aspect is transcendental at early levels of education, since all the mental activity of 
the child is situated within and supported by a more or less conducive cultural context (Bruner, 1997).

\section{Theoretical framework}

The EHEA has contributed to the widespread use of the term 'competence', which is the result of the need to go beyond a purely transmissive education. This type of education was frequently a mechanical and de-contextualized acquisition of conceptual knowledge, which was difficult to transfer later to real individual situations. Learning is currently understood as a complex skill which includes knowledge, attitudes and procedures for learning to know, learning to be, learning to do and learning to live together (Delors, 1997) and therefore includes learning from a sociocultural viewpoint. The conceptualization of the term 'competence' is, however, still controversial (Zabala \& Arnau, 2007).

In this study, based on Perrenoud's proposals (2004) the concept of 'competence' is taken to mean: "Capacity to mobilize various cognitive resources to deal with a certain type of situation" (p.11). This definition highlights four aspects which emphasize the complex and contextualized character of the concept, making it similar to the concept of strategy (Monereo, 2005):

1) Competencies are not in themselves knowledge, skills or attitudes, although they mobilize, integrate and orchestrate these resources.

2) This mobilization only becomes relevant in a specific situation, and each situation is unique, although analogy with others may be used.

3) Exercising the competence involves complex mental operations, based on thought patterns, which allow an action that is relatively adapted to the situation to be determined and performed.

4) Professional competences are created by training, and also as the result of day-today hands-on experience gained as the subject moves from one situation to another.

The author proposes a taxonomy of competences divided into the following 10 dimensions: 
Table 1. Reference competences (Perrenoud, 2004)

1. Organize and encourage learning situations

2. Manage the learning progress

3. Draw up and develop differentiating devices

4. Involve students in their learning and work

5. Teamwork

6. Take part in managing the school

7. Inform and involve the parents

8. Use new technologies

9. Face up to professional duties and ethical dilemmas

10. Organize continuous training.

Perrenoud's third group of competences should also be considered here: Draw up and develop differentiating devices. This includes a specific competence: develop cooperation between students and some simple types of mutual teaching/learning, which has been taken as the main theme of this paper. According to this author, teamwork is not simply doing together what could be done separately, and even less 'watching' the group leader or most able student doing it. In other words, the need for interdependence between the group members is emphasized. The real teaching challenge is to invent tasks which require true cooperation, which provoke sociocognitive conflict and stimulate metacognitive activity. In fact, this favours didactic effectiveness rather than efficient action. This means that pupils can engage in mutual teaching and encourages the use of the teaching contract for certain tasks. The result will be classrooms which encourage a culture of solidarity, tolerance and reciprocity, leading to the regular use of the class council.

On the other hand, the mindset of the teachers must be more receptive to institutional pedagogy, concentrating less on didactic interaction and becoming more sensitive to cooperative management of the classroom as a community and city, setting up internal institutions which offer opportunities both for learning democracy and for organising group work.

The psychological perspective

Studies of the significance and transcendence of group work from a psychological approach are linked to the interpretation different authors or trends have made of the wider context of social interaction and its repercussion on different human dimensions. Different 
theoretical perspectives of group work from a psychological viewpoint, based on FernándezBerrocal and Melero (1995), are shown schematically below.

\section{Those which take Piaget's cognitive conflict construct as reference}

These theories prompted American research into social interaction and social constructivism. Here, Piaget conceived cooperation to be a parallel form of logic where the child will discuss propositions which lead to disequilibrium. This will produce an attempt to find a logical resolution to this internal cognitive conflict, which then opens the door to achieving cognitive development. For Piaget, the interlocutors must possess a common language and system of ideas and must allow reciprocity when attempting to examine and resolve differences of opinions.

\section{Vygotsky's point of view}

Vygotsky's concept for understanding the interactive and social nature of the child is the zone of proximal development. In it, the child acts beyond the limits of his individual capacity, with the help of someone with more experience. The idea of cooperation when sharing thought processes is related to the linguistic concept of intersubjectivity, which centres on the shared comprehension of a topic by people who work together, taking into account the viewpoint of each one. Vygotsky's work clearly had a significant influence on current socioconstructivist-based educational psychology. Concepts including scaffolding, learning community and distributed cognition were inspired by his contributions.

Among the most specific peer relationship-centred procedures the most widely known is reciprocal teaching (Reciprocal Teaching; Palincsar Stevens \& Gavelek, 1989). This is a cooperative learning system aimed at improving text comprehension, based on discussions of meaning. The instrumental axis is the use of four strategies: asking, summarising, predicting and clarifying, selected because they are part of the activities of 'good readers' and act as self-review learning mechanisms.

\section{US based research into cooperative work}

This is fundamentally of two types: 1) Cooperative Learning; 2) Peer Tutoring. The term 'cooperative learning' refers to a wide ranging, heterogeneous group of structured 
instruction methods where the students work together on academic tasks, normally in groups or teams of 4-6 students.

The main methods of cooperative learning include: Jigsaw (Aronson, 1978); Learning Together (Johnson \& Johnson, 1991); Group Investigation (Sharan et al., 1985); Finding Out (Cohen, 1986) and the Student Team Learning techniques developed by Slavin (1995). Johnson et al. (1999), consider two characteristics of cooperative learning which in our opinion are very important. The first is the social skills needed for cooperation (appropriate communication, constructive conflict resolution, participation, acceptance of others). These skills have to be taught so that they can be put into practice. The second is group selfreflection, where the group members spend time reflecting together on the work process, depending on their relationships and the aims of the work, and then take decisions on readjustment and improvement.

Peer tutoring can be defined as a paired instruction system where one of the partners teaches the other to solve a problem, complete a task, learn a strategy or master a procedure within an externally planned framework. The main characteristics of peer tutoring are: 1) setting up a teaching /learning situation or context with two students, where support and guidance behaviour is present; 2) involving -to some extent- asymmetrical relationships on a one- to- one basis; 3) working towards a stated goal to be achieved by the pair. Apart from these aspects common to all peer tutoring situations, each of them has significant peculiarities leading to different modalities, with different levels of structuring, from situations where there are no external impositions to the more 'technical' and heavily prescriptive ones: (“Structured Tutoring”, "Programmed Tutoring”, "Scripted Tutoring”, etc.; Devin-Sheehan et al. 1976; Topping \& Whiteley, 1990; Wheldall \& Colmar, 1990).

Finally, it should be noted that the term collaborative learning is increasingly being used as a synonym for cooperative learning. However, the classical distinction proposed by Damon \& Phelps (1989) should be kept in mind, with the three dimensions or scenarios of educative peer interaction (tutoring, cooperating and collaborating). This proposal refers fundamentally to the type of interaction where two elements can be highlighted: the equality of the roles of the interacting partners (symmetrical or asymmetrical relationships) and mutuality, understood as the connection, depth and bi-directionality of the communicative transactions. 


\section{Integrative perspective}

With the above theoretical approaches as a starting point, an attempt will now be made to integrate the different approaches and draw up a working model for the analysis of the relevant study data which will then be presented below. This model is based on the following criteria (see Figure 1):

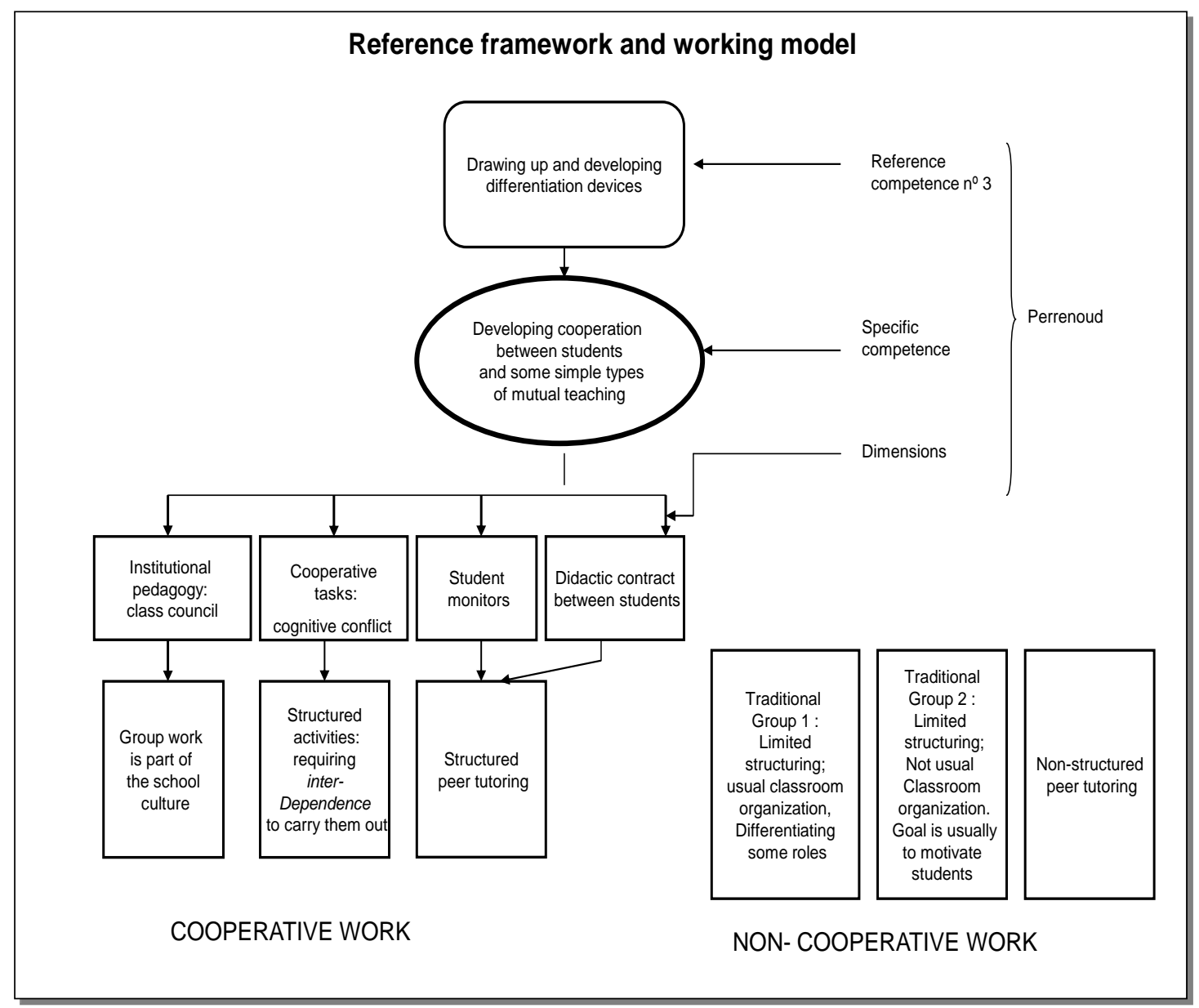

Figure 1. Reference framework and working model

Aims

With the aim of improving initial teacher training the proposed objectives are to ${ }^{1}$ :

1. Describe the perception that a group of primary school teachers in the Madrid region has regarding cooperative learning.

\footnotetext{
${ }^{1}$ The perception and putting into practice of cooperative learning will indicate the teachers' concepts of it, while the final aim is to examine our own praxis and optimize it.
} 
2. Analyse their account of how they conduct cooperative work in the classroom.

3. Draw conclusions and implications for initial teacher training in this competence.

\section{Method}

\section{Participants}

The study was conducted with a sample of 48 teachers from state schools (93.6\%) and grant- aided schools (6.4\%) in the Madrid region. The majority of the teachers were women (77.1\%), over $45(56.3 \%)$ with more than 20 years of teaching experience $(54.2 \%)$, who teach classes in more than one primary education year group (40.9\%) and who are also class tutors for one of these groups $(57.8 \%)$.

\section{Procedure}

With the aim of improving initial teacher training, an interdisciplinary research group was set up and validated in 2005 by the Complutense University, Madrid (UCM) (Group 940562). Since then, the Group has carried out in-depth studies at different analytical levels, with funding from the UCM and from the Madrid regional government.

The first level of analysis could be called the identification level. Through a funded project (2004 Call for proposals) ${ }^{2}$, a descriptive "ex post facto" study was carried out, surveying 344 practising primary teachers working in 250 schools in the Madrid region. Using a Likert-type questionnaire, the participants were presented with a set of indicators linked to Perrenoud's 10 dimensions which they had to score on: a) importance, b) practical usefulness c) relevant training received. Although the results of this first phase are not the object of this article, it is interesting to point out: 1) the discrepancy between theoretical orientations and professional practice. 2) the general perception that the initial training received was insufficient (Fernández-Lozano, et al., 2006; De-Juanas, et al., 2008; Pesquero et al. 2008; De-Juanas, et al. 2009; Martín del Pozo \& De-Juanas, 2009).

\footnotetext{
${ }^{2}$ Las competencias profesionales de los maestros de Primaria de la Comunidad de Madrid: percepciones y necesidades formativas en el marco del EEES (Professional competences of Primary School Teachers in the Madrid Community: perceptions and training needs within the EHEA framework)
} 


\section{Our study}

The data presented below correspond to the second more in-depth phase of the study which we have called the declarative level. This study was facilitated by funding from various Spanish public bodies ${ }^{3}$. Those who participated in this phase were the practising teachers who had been surveyed in the first phase and who had expressed their willingness to examine in greater detail certain aspects of the research. These teachers were given a semistructured interview using the phenomenographic approach, to explore how the teachers interpreted different experiences related to their professional experience and in particular those related to cooperative learning. At a future date, the third phase or action level will be conducted to study, through classroom observation, the competency aspects which are developed in teacher's everyday practice.

For the purpose of this study semi-structured interviews were conducted. This technique is part of a phenomenographic approach intended to describe and categorize the qualitatively different ways people experiment and interpret their experience, in this case the professional experience of the primary school teacher. The interviews focused on the following aspects:

- How the practising teachers interpret the most relevant results obtained from the preliminary survey they had taken part in previously, to discover to what extent they agree with the results.

- $\quad$ How they understand and put into practice the skills linked to specific competences.

- $\quad$ The training they received in this specific competence.

In line with the aim of this paper, comments were collected related to the item:

I encourage cooperative learning with my students, which were then arranged in three groups: 1) evaluating the competence; 2) using it in practice; 3) acquiring the competence.

\footnotetext{
${ }^{3}$ Competencias profesionales y Formación del Profesorado. Estudio con Maestros en Formación y en Activo de la Comunidad de Madrid. Dentro del Programa: "Creación y consolidación de grupos de investigación" contrato Programa para la regulación del marco de cooperación en el sistema regional de investigación científica e innovación tecnológica. IV PRICIT (2005-2008) (CCGO6-UCM/HUM-1034).

Professional competences and teacher training. Study with trainee and experienced teachers in the Madrid Community. Within the Programme: "Creating and consolidating research groups" Contract programme for regulating the cooperation framework in the regional system for scientific research and technological innovation . IV PRICIT (2005-2008) (CCGO6-UCM/HUM-1034).
} 
Most of the results shown in the following sections were possible thanks to the interviewers' ability to examine in detail the most important variables related to the topic under discussion.

\section{Data Analysis}

The procedure for analysing the content of the interviews was based on Bardin's (1977) content analysis, following the sequence described below:

1. The recordings of the 48 interviews carried out were transcribed.

2. A numerical code was assigned to the interviews including: Interviewer identification $\mathrm{n}^{\mathrm{o}}$; interview $\mathrm{n}^{\mathrm{o}}$ and questionnaire number completed by the interviewee in the previous survey. E.g. E1-155, corresponds to interviewer E, interview 1 with interviewee teacher who completed questionnaire 155.

3. The Information Units were located following the interview protocol. These units are the interviewee's responses to the training received in each of the competences considered, as well to the question on how they evaluate the initial training.

4. The Information Units were reformulated into Synthesis Proposals, as a previous step to interpretation, i.e. with a very low level of inference.

5. Finally, the interpretation of the synthesis proposals was conducted by the research group which discussed and agreed on the different categories in the interviewee responses according to the theoretical framework shown above (Figure 1).

Example (Information unit E.1-155):

\section{Transcription:}

Interviewee: I'm very surprised at the evaluation (referring to the previous result of the competence associated with the cooperative work system), because I think that this isn't usually done unless you're in a particular group or school, and that's why I'm so surprised at the high score. I think it's important because I believe that this is a way of putting into practice the values I try to transmit. So I've read a little on cooperative learning and I'd like to find a specific training course on this to find out what it's really all about, because maybe the cooperative learning I use is just something I put together as I go along. When I can, I 
get the children to work in a group and I use the smaller group and the bigger group and I group some pupils with others. I mean, I try to get them to help each other, but I know that the theoretical background is missing and I'd love to find a really good course all about cooperative learning and how to put it into practice.

Interviewer: So you mean the theoretical background is missing? From an organizational point of view could that be a problem for you? Is individual teaching different from group teaching in, for example, control or discipline?

Interviewee: Of course! Obviously there are problems. When you want to do cooperative work, it's much harder to keep discipline, order and silence.

Interviewer: But does that actually prevent you from doing it?

Interviewee: No. For example I use groups in class and it's a lot of work, but once or twice in twenty odd years I have done it like that, separately, and I think it only lasted two or three days, because it goes completely against my own convictions. So I prefer to make the effort to keep order, with self-discipline and silence even though it's much more work.

Interviewer: Well, as you can see (referring to the results shown), the scores for training are also quite low.

Interviewee: Maybe it's different now. When I was a student I never even heard of it! (laughter).

Synthesis Proposal:

Disagreement with the evaluation given by other colleagues since this teacher thinks this is not real and the results are overvalued. She considers it fundamentally a procedure for transmitting values but which makes order and discipline in the classroom more difficult. This teacher uses the small and the large group, intuitively, so that they help each other. She did not receive any specific teacher training and recognises the lack of, and need for, specific training in this area.

\section{Categorisation:}

- With regard to the evaluation of the results: Considers it is overvalued by other colleagues, although considers it important for socialization.

- With regard to putting it into practice: Very seldom used. Creates problems with order in the classroom. Little teacher control.

- $\quad$ Initial training: None or not enough. 


\section{Results}

We begin by presenting the data referring to the teachers' evaluation of the cooperative learning competence, and then comment on those referring to teacher performance and the training received in this competence.

The table below shows the results collected for both the evaluation of the preliminary questionnaire results completed by colleagues (very much in favour of this type of work), as well as the interviewee's own criterion, since these are difficult to separate. The results show the percentages obtained from a total of 67 statements:

How do you interpret the evaluation made by your colleagues with regard to the cooperative learning methodology?

Table 2. Interpretation of the evaluation made by colleagues of the cooperative learning methodology

\begin{tabular}{lrr}
\hline \multicolumn{1}{c}{ Categories } & Frequencies & $\begin{array}{c}\text { Percentage } \\
\text { valid }\end{array}$ \\
\hline Consider it is important (no reasons given) & 11 & 16.4 \\
\hline $\begin{array}{l}\text { Consider it is fundamental for socialization-related reasons } \\
\text { (helps to integrate children with difficulties) }\end{array}$ & 15 & 22.4 \\
\hline Consider it is important for learning- related reasons & 10 & 14.9 \\
\hline Consider it is fundamental for student motivation-related reasons & 6 & 9 \\
\hline Consider it is important for teacher-related reasons & 2 & 3 \\
\hline Consider that cooperative work causes various problems & 14 & 20.9 \\
\hline Consider other agents should be involved (e.g.: parents, other teachers) & 5 & 7.4 \\
\hline Give reasons for not using it & 4 & 6 \\
\hline
\end{tabular}

If you do use cooperative work, how do you set it up in the classroom with your students?

When grouping the responses obtained, it was decided to use flexible criteria to include all the types of work found. The results are shown in the Table below. 
Table 3. How do you use cooperative work with your students in the classroom?

\begin{tabular}{lrr}
\hline \multicolumn{1}{c}{ Categories } & Frequencies & $\begin{array}{c}\text { Percentage } \\
\text { valid }\end{array}$ \\
\hline $\begin{array}{l}\text { Teamwork is stated as part of the school's educational philosophy. This } \\
\text { proposal contains the characteristics of institutional pedagogy where the } \\
\text { classroom is understood as a learning community. }\end{array}$ & 1 & 2.1 \\
\hline $\begin{array}{l}\text { They use cooperative learning. They set up structured activities } \text { which require } \\
\text { the } \text { interdependence of the different members to carry them out. }\end{array}$ & 2 & 4.2 \\
\hline $\begin{array}{l}\text { Traditional Group I. Although there is no clear structuring of activity and } \\
\text { division of work, some characteristics show the interest of the teachers in this } \\
\text { kind of work where the classroom is organised in small groups, with different } \\
\text { roles and attention is paid to the acquisition of certain social skills. }\end{array}$ & & \\
\hline $\begin{array}{l}\text { Traditional Group II. They use group work although less than the category } \\
\text { above. In their work the groups are hardly controlled at all by the teacher and the } \\
\text { end aim is often motivation rather than task centred. }\end{array}$ & 12 & 18.7 \\
\hline They develop structured peer tutorials. & 0 & \\
\hline $\begin{array}{l}\text { They develop non-structured peer tutorials. The interest is fundamentally centred } \\
\text { on help by more expert students for those who have most difficulties, mainly } \\
\text { through pair work, without any type of previous planning }\end{array}$ & 4 & \\
\hline $\begin{array}{l}\text { They do not use group work, either because they do not agree with this approach } \\
\text { or because of the problems it creates. }\end{array}$ & 8 & 16.6 \\
\hline $\begin{array}{l}\text { They do not interpret the question adequately and/or the response is too } \\
\text { ambiguous. }\end{array}$ & 12 & 25 \\
\hline
\end{tabular}

How and when did you train to work using the cooperative learning methodology?

Table 4. How and when did you train to work using the cooperative learning methodology?

\begin{tabular}{lcr}
\hline \multicolumn{1}{c}{ Categories } & Frequencies & $\begin{array}{c}\text { Percentage } \\
\text { valid }\end{array}$ \\
\hline $\begin{array}{l}\text { Consider that their initial teacher training is sufficient. They are satisfied with } \\
\text { the training received in their teacher training course. }\end{array}$ & 8 & 25 \\
\hline $\begin{array}{l}\text { Consider that their initial teacher training was not sufficient. The general idea is } \\
\text { that in the University cooperative learning is not dealt with in enough depth, } \\
\text { although they had received some kind of training. }\end{array}$ & 7 & \\
\hline Consider that their initial teacher training was nil or very deficient. & 9 & 21.8 \\
\hline $\begin{array}{l}\text { Develop their lifelong continuous learning in training experiences. They refer to } \\
\text { participation in projects promoted by the university, to courses and interchange } \\
\text { of experiences with groups of teachers committed to pedagogical innovation. }\end{array}$ & & \\
\hline $\begin{array}{l}\text { Self-training: they continue to train themselves through reading and research or } \\
\text { through their own teaching experience. }\end{array}$ & 4 & 12.5 \\
\hline
\end{tabular}

\section{Discussion}

The first point to emphasize is that $37 \%$ of the teachers interviewed did not interpret the significance and scope of the question appropriately. As can be seen from the Tables, there is a clear contradiction between the importance given to this kind of learning (Table 3) and its planned and systematic use in practice (Table 4). 
Table 3 shows a fairly widespread opinion regarding the relevance of cooperative work, which often seems to appear as 'slogans', but is very seldom expressed as specific points which could be approached through teamwork: conflict solving, exploring and processing previous ideas, working on problems or interesting projects which cannot be easily dealt with in any other way, etc. Here, we agree with Kagan y Kagan (2008) who point out that it is still a mystery why some teachers do not see the need for a gradual implementation of basic successful social interaction and cooperative behaviour, in spite of the fact that this is a generally recommended practice.

Among the motives highlighted for their declared interest in group work, the teachers mention the socializing aspect. This is due to the multiple problems inherent in the mixed classroom and is something to which some teachers would like to pay special attention as can be seen from their opinions of their own performance (Table 4). Recent findings by other researchers corroborate our data. For example, a similar study carried out by Gillies \& Boyle (2011) over a two year period with Australian teachers highlights this evidence. Here, we agree with Sharan (2010) who mentions that when cooperative learning is successfully implemented, it offers students a learning experience in an environment where knowledge is dynamic and creative, growing out of student interaction even when they are from different backgrounds, with different interests, experience and ideas.

In any case, as we consider that cooperative learning is an important tool, it is a pity that teachers' efforts are not channelled more effectively by incorporating work methods which may be useful to them. From a socializing aspect, the emphasis is placed on integrating the different cultures coexisting in the classroom due to the migratory phenomenon, but there are no allusions (or reference to work methods) to certain relevant aspects of education today: basically those related to questions of gender and sexual identity.

Aspects related to learning are the third most mentioned category (Table 3). Teachers' concerns and how they deal with them are intimately linked to the above: the learning difficulties of their pupils, whether they be due to social reasons or capacity, and their need for help from more able classmates. Although peer tutoring is an under-represented category (Table 3: 7\% of responses), this concern also extends to other types of group work (Table 4). 
With regard to motivation, an intrinsic quality of cooperative work, this is mentioned as one of the positive qualities of this learning mode (Table 3: 13\% of responses), and when it is attempted in practice (Table 4), the pupils seem satisfied, in the teachers' opinion.

Logically, a significant percentage of the responses (30\%) refer to the difficulties inherent in group work and some of them (11\%) mention the need to involve other agents and agencies. Evidently, group work implies many difficulties and cooperation with other professionals is essential. However, in spite of these difficulties, the percentage of those who say they do not put it into practice, and give reasons for this, is lower than $9 \%$.

Finally, and what is especially significant, not a single case has been found where the teachers have used ICT to encourage student socialization and/or learning through distancebased cooperation with other peer groups. It seems clear that the teachers themselves have training needs in this area, as their use of ICT is underdeveloped and they are not fully aware of its transcendence from a socioconstructivist viewpoint (Coll \& Monereo, 2008).

Mention should also be made of the low profile of these methods and techniques in the initial teacher training. It is obviously not easy to introduce cooperative learning into schools if it is not included in the university classroom as a basic teaching-learning method. Although the results commented on above come from a teacher cohort where the majority have many years of professional experience, we would suggest from our own experience as university teachers that this is still not being successfully addressed. However, given the limitations of the study sample and its selection, the results have to be considered with some caution.

The results of a recent study carried out with groups of students in different degree courses, mainly teacher training (Magisterio) (Fernández Lozano et al., 2007), coincide with the opinions of the practising teachers presented here. For example, the importance of group work for future professional activity is recognized, but linked to an unawareness of the basic cooperative work techniques. There is also overall satisfaction with regard to teamwork, but this is based mainly on informal aspects and because it encourages social skills. In the same context, references are found to international studies which corroborate these findings (Gillies, 2003, 2004, 2008; Rojas-Drummond \& Mercer, 2003; Webb, 2009). 


\section{Training implications}

In conclusion, we consider that important difficulties still exist when incorporating cooperative work into the primary school classroom. We agree with the diagnosis made by Domingo (2008) regarding the types of reasons which hinder putting cooperative learning into practice: a) Policy reasons (policies adopted by the university, school, department, group, or linked to employment category, contractual circumstances, etc.); b) cultural reasons (customs, habits, styles, how things are done, techniques, personal experience, prejudices, etc.) and c) technical reasons (available space, number in class, type of pupils, length of sessions, type of activity, etc.).

In view of the results obtained, the following proposals are made for the inclusion of cooperative learning in teacher training courses:

For the students (future teachers), it is essential to promote interdependence between the members of a work team to encourage cooperative teamwork. At present, student interdependence means loss of control by the university teacher (Ruys, Van Keer \& Aelterman, 2011). Similarly, the idea should be discarded by teacher trainers that group work is activity based on camaraderie, where individual responsibilities are diluted to the extent that some students may end up working on behalf of other less responsible members of the group.

For the activity, the task must not lose all meaning in an attempt to make it overly operational, which may lead to it being dealt with very superficially, approaching the principles of the traditional learning paradigm. Just as Kwaku \& Elen (2011), we understand that the methods must be appropriate for the existing conditions, students and needs. We also insist on the implementation of certain basic transversal skills (listening, assertiveness, tolerance, etc.) through different activities.

For the teaching staff responsible for teacher training, we consider that collaboration between teachers of different disciplines and with other professionals is desirable, to pool ideas on interesting projects and tasks involving interdependence and intended to develop basic competences for the future professional careers of the students in different degree courses (González Ballesteros, M., Fernández Lozano, P. \& Martín del Pozo, R., 2008). 
However, the course methodology has to be structured realistically, adapting the time available to different needs.

For the institutions, appropriate scenarios should be facilitated so that university teaching staff can reflect on their own teaching with a view to optimizing it. This involves encouraging the creation of teams of teachers committed to change and innovation in teaching. It would be appropriate to reduce student/teacher ratios and create spaces to generate a classroom environment favourable to cooperative work. Finally, we consider that university teaching staff must be trained in the use of new technologies and that teaching centres should be equipped with the resources needed to enable cooperative work inside and outside the classroom.

In summary, cooperation should be learned by exercising it, as well as acquiring knowledge, and as an instrument to facilitate a series of conditions to generate and consolidate competences related with learning to know, learning to be, learning to do. Cooperation is more than just a way of learning; it is a culture which should be integrated into how we interact with those around us. However, we must consider that perhaps the university context is not very conducive to teachers becoming seriously involved in this way of working.

Some of these difficulties have already been mentioned in the case of the primary school teachers, particularly the individualist culture, where academia is a leading exponent. This individualist culture is contrary to a 'multidisciplinary educational approach', intrinsically linked to training in future professional competences (Zabala y Arnau, 2007) where cooperation between teachers is a requirement.

In any case, integration in the EHEA should facilitate recycling of university teachers, increasing the value of teaching and innovation, given that its real weight in academic life is still very low.

On the other hand, university teachers have deep-rooted conceptions of learning linked to the capacity of the individual student and content mastery. They continue to understand cooperative work and other constructs from the psychopedagogic environment as nonessential aspects of their work. This way of thinking is difficult to change unless there is 
clear institutional support for creating conditions which facilitate a new learning culture based on cooperation. Evidently, research into cooperative learning is casting light on the challenge involved in encouraging more initial training for teaching staff in this type of work. In agreement with Sharan (2010, p. 308), we consider that those in positions of political responsibility must take appropriate steps to shed light on the factors preventing the sustainable application of cooperative learning. 


\section{References}

Bardin, L. (1977). Analyse de contenu. Paris: Presses Universitaires de France. (Trad. Cast.: Análisis de contenido. Madrid: Akal, 1986).

Bruner, J. (1997). La educación, puerta de la cultura. Madrid: Visor. (The Culture of Education (1996).

Coll, C. and Monereo, C. (Eds.) (2008). Psicología de la educación virtual. (Psychology of virtual education) Madrid: Morata

Damon, W. \& Phelps, E. (1989). Critical distinctions among three approaches to peer education. International Journal of Educational Research, 13, 9-19.

Devin-Sheehan, L., Feldman, R.S., \& Allen, V. L. (1976). Research on children tutoring children: a critical review. Review of educational Research, 46, 355-385.

De-Juanas, A. \& Fernández-Lozano, P. (2008). Competencias y estrategias de aprendizaje. Reflexiones sobre el proceso de cambio en el EEES. (Competences and learning strategies. Reflections on the change process in the EHEA). Cuadernos de Trabajo Social, 21, 217-230.

De-Juanas, A., González-Ballesteros, M., Fernández-Lozano, P. \& Martín del Pozo, R. (2008). La formación inicial en competencias profesionales de los maestros de Primaria. (Initial training in professional competences for primary school teachers) Paper presented at the V International Congress for Psychology and Education. Oviedo: Ediciones de la Universidad de Oviedo.

De-Juanas, A., Fernández-Lozano P., Martín del Pozo, R., González-Ballesteros, M., Pesquero, E. \& Sánchez, E. (2009). Comparative study of the evaluation of professional competences by experienced and trainee Spanish primary teachers. European Journal of Teacher Education, 32 (4), 437-454.

Delors, J. (Coord.) (1996). Educació: hi ha un Trevor amagat a dins Informe para la UNESCO de la Comisión Internacional sobre Educación para el siglo XXI. Barcelona: Centre UNESCO de Catalunya. (Learning: The Treasure Within. Report to UNESCO of the International Commission on Education for the Twenty-first Century. 
Domingo, J. (2008). El aprendizaje cooperativo. (Cooperative Learning) Cuadernos de Trabajo Social, 21, 231-246.

Fernández-Berrocal, P. \& Melero, Ma A. (Comps.) (1995). La interacción social en contextos educativos. (Social interaction in educational contexts) Madrid: Siglo XXI.

Fernández-Lozano, P.; González-Ballesteros, M.; De-Juanas, A. \& Martín del Pozo, R. (2007). Relato de nuestra experiencia en aprendizaje cooperativo. (Our experience in cooperative learning). In: Ma A. Simón; Ma L. González \& C. E. Vivaracho (Eds.), Séptima Jornada sobre Aprendizaje Cooperativo. Valladolid: Mata Digital.

Gillies, R. (2003b). Structuring cooperative group work in classrooms. International Journal of Educational Research, 39, 35-49.

Gillies, R. (2004). The effects of cooperative learning on junior high school students during small group learning. Learning and Instruction, 14, 197-213.

Gillies, R. (2008). The effects of cooperative learning on junior high school students' behaviours, discourse and learning during a science-based learning activity. School Psychology International, 29, 328-347.

Gillies, R. \& Boyle, M. (2011). Teachers' reflections of cooperative learning (CL): a two year follow up. Teaching Education, 22, 1, 63-78

González-Ballesteros, M.; Fernández-Lozano, P. \& Martín del Pozo, R. (2008). Las actividades prácticas como instrumento para el desarrollo de competencias en los futuros profesionales de la educación.(Practical activities as a tool for developing competences in trainee teachers) Revista Interuniversitaria de Formación del Profesorado, 63, 141-160.

Hernández Pina, F., Martínez-Clares, P., Da Fonseca, P. \& Rubio, M. (2005). Aprendizaje, competencias y rendimiento en educación superior (Learning, competences and performance in higher education). Madrid: La Muralla.

Johnson, D. W., Johnson, R.T., \& Holubec, E. (1999). El aprendizaje cooperativo en el aula. (Cooperative learning in the classroom) Barcelona: Paidós.

Johnson, D. W. \& Johnson, R.T. (1991). Learning Together and Alone. Cooperative, Competitive and Individualistic learning. Needham Heights: Allyn and Bacon.

Kagan, S. \& Kagan, M. (2008). Cooperative Learning. California: Kagan Publishing. 
Kwaku, S. \& Elen, J. (2011). Investigating the impact of positive resource interdependence and individual accoutability on students' academic performance in cooperative learning. Electronic Journal of Research in Educational Psychology, 9 (1), 73-94.

Lobato, C. (1998). El trabajo en grupo. Aprendizaje cooperativo en Secundaria.(Group work. Cooperative learning in secondary education) Bilbao: Heuskal Herriko Unibertsitatea.

Longworth, N. (2005). El aprendizaje a lo largo de la vida en la práctica. Transformar la educación en el siglo XXI. Barcelona: Paidós. Lifelong Learning in Action: transforming education in the $21^{\text {st }}$ century (2003).

Martín del Pozo, R. \& De-Juanas, A. (2009). La formación inicial en competencias valorada por los maestros en activo. (Initial training in competences evaluated by practising teachers). REIFOP, 12 (3), 59-69. (Enlace web:http//www.aufop.com)

Monereo, C. (Coord.) (2005). Internet y competencias básicas. Aprender a colaborar, a comunicarse, a participar, a aprender. (Internet and basic competences. Learning to communicate, participate and learn).Barcelona: Graó.

Parcerisa Aran, A. (Coord.) (2005). Materiales para la docencia universitaria. (Materials for university teaching) Barcelona: Octaedro/ICE-UB.

Perrenoud, Ph, (2004). Diez nuevas competencias para enseñar. Barcelona: Graó [Dix nouvelles competences pour enseigner. Invitacion au voyage (1999)].

Pesquero, E., Sánchez, E., González-Ballesteros, M., Martín del Pozo, R., Guardia, S., Cervelló, J., Fernández-Lozano, P., Martínez, M., \& Varela, P. (2008). Las competencias profesionales de los Maestros de Primaria.(The professional competences of primary teachers) Revista Española de Pedagogía, 241, 447-466.

Rojas-Drummond, S., \& Mercer, N. (2003). Scaffolding the development of effective collaboration and learning. International Journal of Educational Research, 39, 99111 .

Ruys, I., Van Keer, H., Aelterman, A. (2011). Student teachers' skills in the implementation of collaborative learning: A multilevel approach. Teaching and Teacher Education 27, 1090-1100

Sharan, Y. (2010). Cooperative Learning for Academic and Social Gains: valued pedagogy, problematic practice. European Journal of Education,45, 2, 300-313. 
Slavin, R. E. (1995). Cooperative Learning. Massachusets: Allyn \& Bacon.

Topping, K. \& Whiteley, M. (1990). Participant evaluation of parent-tutored and peer-tutored projects in reading. Educational Research, 32, 1, 14-27.

UNESCO (2005). Towards Knowledge Societies. UNESCO World Report Paris: UNESCO.

Webb, N. (2009). The teacher's role in promoting collaborative dialogue in the classroom. British Journal of Educational Psychology, 79, 1-28.

Wheldall, K. \& Colmar, S. (1990). Peer tutoring for low-progress readers using "pause, prompt and praise”. In H. C. Foot, M. J. Morgan and R. H. Shute (Comps.), Children helping children. Chichester: John Wiley and Sons.

Zabala, A. \& Arnau, L. (2007). Cómo aprender y enseñar competencies (How to learn and teach competences). 